Génét. Sél. Evol., 1988, 20 (2), 255-258

\title{
Note
}

\section{Types of red cell potassium in seven Spanish native breeds of cattle}

\author{
Paquita GONZALEZ *, Maria Jesús TUÑON * and M. VALLEJO ** \\ * Biología, Facultad de Veterinaria, Universidad de León, \\ Campus de la Vegazana, 24007 Leon, Spain \\ ** Departamento de Genética, Facultad de Veterinaria, Ciudad Universitaria, 28040 Madrid, Spain
}

\begin{abstract}
Summary
The distribution of red-cell potassium was studied in seven Spanish native breeds of cattle. Two classes of cattle were identified : one with potassium concentrations higher than 46 m-equiv/l (HK) and one with lower concentrations (LK). Mean values for LK animals varied from 22.6 to $29 \mathrm{~m}$-equiv/1. For $\mathrm{HK}$ animals the means ranged from 50.8 to $66.1 \mathrm{~m}$-equiv/1.
\end{abstract}

Key word: red cell potassium, cattle, Spanish breeds.

Résumé

Types de potassium érythrocytaire de sept races bovines autochtones espagnoles

L'étude de la distribution du potassium érythrocytaire dans sept races bovines autochtones espagnoles a mis en évidence deux populations : l'une où les animaux ont des concentrations de potassium érythrocytaire supérieures à $46 \mathrm{~m}$-équiv/1 (HK), l'autre où les concentrations sont inférieures à ce seuil (LK). Les valeurs moyennes du potassium érythrocytaire chez les animaux LK varient entre 22,6 et 29 m-équiv/1, et chez les animaux HK entre 50,8 et 66,1 m-équiv/1.

Mots clés : potassium érythrocytaire, bovins, races espagnoles.

\section{Introduction}

Several authors (Evans \& Phillipson, 1957 ; Howes et al., 1961 ; Evans, 1963) have contributed data on red-cell potassium concentrations in cattle, but ELLORY \& TUCKer (1970) were the first researchers to point out the existence of two types of populations in this regard, in Jersey cattle. They suggested the inheritance of the potassium type in cattle was simple, as in sheep (Evans \& KING, 1955), the LK gene being dominant over the HK one. Later RASMUSEN et al. (1974) indicated that a major difference in potassium levels of red cells in cattle may be controlled by two codomi- 
nant alleles. Red-cell potassium has also been shown to be polymorphic in buffaloes (Pandey \& Roy, 1968 ; Sengupta, 1974) and yaks (KameneK, 1977).

The purpose of the present paper is to describe the existence of polymorphism of the erythrocyte potassium in six of the seven Spanish native cattle breeds studied.

\section{Material and methods}

Blood samples were taken from a total of 683 adult animals belonging to seven native Spanish cattle breeds : Sayaguesa (138 head), Morucha (101), Alistana Sanabresa (124), Blanca Cacereña (62), Cárdena Andaluza (25), Asturiana de los Valles (127) and Asturiana de la Montaña (106). The sampling of each breed was carried out at random from private farmers. The majority of the animals studied were cows.

The blood samples were obtained by jugular venipuncture directly into heparinized tubes. Haematocrit value (pcv) was determined by the microhaematocrit method. Concentrations of $\mathrm{K}^{+}$in whole-blood $(\mathrm{Kwb})$ and plasma $(\mathrm{Kp})$ were estimated by flame photometry using the method described by Evans (1954). Red-cell $\mathrm{K}^{+}$concentration was calculated indirectly, by means of the formula :

$$
\mathrm{Ke}=\mathrm{Kp}+\frac{\mathrm{Kwb}-\mathrm{Kp}}{\mathrm{pcv} / 100}
$$

\section{Results and discussion}

Two different cattle populations were found regarding red cell potassium concentrations. The choice of the cut-off point, according to the bibliography consulted (ELLORY \& Tucker, 1970 ; Christinaz \& Schatzmann, 1972 ; Komatsu et al., 1980) is subjective and made at the class or value where fewest population overlaps are noticed. Using this criterion, and with a view to giving it a statistical foundation, and to determining a cut-off point, we carried out a $\chi^{2}$ test of adjustment to normality for each breed, considering populations of up to 46,49 and $52 \mathrm{~m}$-equiv/1 and grouping them into classes of $3 \mathrm{~m}$-equiv/1. From the results obtained in this study, we propose that it be set at 46 m-equiv/1 of red cell $\mathrm{K}^{+}$.

In a previous study of 14 Spanish goat breeds with a high number of LK and HK animals we found a clear bimodal distribution in all breeds. Moreover it was proved by family data that the inheritance of potassium type in goat is similar to that in sheep, the gene for LK being dominant to that for HK type (results to be published). The fact that a clear bimodal distribution has not been observed in cattle might be caused by the small number of HK animals found generally in that species. We hope to collect a sufficiently large number of animals among the offspring of parents with known cell type to prove the genetic basis or to describe how the genes segregate.

From a total sample of 683 animals belonging to seven Spanish breeds of cattle, only 37 showed Ke concentrations over 46 m-equiv/1 (table 1) from which we deduce 
that, in general, LK animals predominate among native Spanish breeds. We would call attention to the lack of $\mathrm{HK}$ animals in the Blanca Cacereña breed. A similar situation was found by Komatsu et al. (1980) for the Holstein breed. Previous work Gonzalez et al. (1987) has shown that the Blanca Cacereña seems to have a different phylogenetic origin from the other six breeds studied in the present work. That difference might explain the lack of HK animals in Blanca Cacereña breed.

TABLE 1

Concentration of potassium in red cells of $L K$ and $H K$ animals (m-equiv/1)

\begin{tabular}{|c|c|c|c|c|c|c|c|c|}
\hline \multirow{2}{*}{ Breed } & \multicolumn{4}{|c|}{ Type LK } & \multicolumn{4}{|c|}{ Type HK } \\
\hline & No & $\%$ & Mean & S.E. & No & $\%$ & Mean & S.E. \\
\hline Sayaguesa & 124 & 89.9 & 28.6 & 0.5 & 14 & 10.1 & 63.7 & 2.5 \\
\hline Morucha . . & 98 & 97.0 & 22.6 & 0.6 & 3 & 3.0 & 58.8 & 3.7 \\
\hline Alistana-S. . & 115 & 92.7 & 28.3 & 0.6 & 9 & 7.3 & 66.1 & 4.2 \\
\hline Blanca-C. & 62 & 100.0 & 23.1 & 0.5 & 0 & - & - & - \\
\hline Cárdena $-A$. & 24 & 96.0 & 27.6 & 1.0 & 1 & 4.0 & 50.8 & - \\
\hline Asturiana-V & 121 & 95.3 & 29.0 & 0.6 & 6 & 4.7 & 50.8 & 1.5 \\
\hline Asturiana-M & 102 & 96.2 & 25.5 & 0.5 & 4 & 3.8 & 60.3 & 4.6 \\
\hline Total breeds & 646 & 94.6 & 26.6 & 0.3 & 37 & 5.4 & 61.1 & 1.8 \\
\hline
\end{tabular}

No : number of animals.

S.E. : standard error.

Mean values for LK animals varied from 22.6 m-equiv/1 (Morucha) to 29 m-equiv/1 (Asturiana de los Valles), the overall mean being 26.6 m-equiv/1. For HK animals the means ranged from 50.8 m-equiv/1 (Cárdena Andaluza and Asturiana de los Valles) to $66.1 \mathrm{~m}$-equiv/1 in Alistana Sanabresa, with an overall mean of $61.1 \mathrm{~m}$-equiv/1.

The mean $\mathrm{K}^{+}$concentrations in LK and $\mathrm{HK}$ animals obtained by us are lower than those obtained by ELRORY \& TUCKER (1970), who indicate a distribution of erythrocyte potassium levels in the LK group of 17 to 62 m-equiv/1 in the Jersey breed and higher than those obtained by Komatsu et al. (1980) for 3 Japanese breeds and 2 European ones, where the mean concentrations in LK animals ranged from 13.4 to $20.6 \mathrm{~m}$-equiv/1 of $\mathrm{K}^{+}$, while those of HK animals were from 34.8 to $41.2 \mathrm{~m}$-equiv/1. This variation is possibly due to breed differences.

Received December 22, 1986.

Accepted May 18, 1987. 


\section{References}

Christinaz P., Schatzmann H.J., 1972. High potassium and low potassium erythrocytes in cattle. J. Physiol., 224, 391-406.

Ellory J.C., Tucker E.M., 1970. High potassium type red cells in cattle. J. Agric. Sci., Camb., 74, 595-596.

Evans J.V., 1954. Electrolyte concentrations in red blood cells of British breeds of sheep. Nature, 174, 931-932.

Evans J.V., 1963. Adaptations to subtropical environments by Zebu and British breeds of cattle in relation to erythrocyte characters. Austr. J. Agric. Res., 14, 555-558.

Evans J.V., King J.W.B., 1955. Genetic control of sodium and potassium concentrations in the red blood cells of sheep. Nature, 176, 171.

Evans J.V., Phillipson A.T., 1957. Electrolyte concentrations in the erythrocytes of the goat and ox. J. Physiol., 139, 87-96.

Gonzalez P., Tuñon M.J., Vallejo M., 1987. Genetic relationships between seven Spanish native breeds of cattle. Anim. Genet., 18, 249-256.

Howes J.R., Davis G.K., Loggins P.E., Hentges J.F., 1961. Blood potassium and sodium of Hereford and Brahman cattle and some breeds of sheep maintained in Florida. Nature, 190, 181-182.

KAMENEK V.M., 1977. Blood potassium polymorphism in yaks. Genetika, 13, 1172-1176.

Komatsu M., Abe T., Nakajima K., Oishi T., Kamenaki M., 1980. Gene frequencies and membrane properties of high potassium type red cells in cattle and goats. Jap. J. Zootech. Sci., 51, 215-222.

Pandey M.D., Roy A., 1968. Potassium and sodium distribution in erythrocyte and plasma of buffalo cows. Curr. Sci., 37, 256.

Rasmusen B.A., Tucker E.M., Ellory J.C., Spooner R.L. 1974. The relationship between the S system of blood groups and potassium levels in red blood cells of cattle. Anim. Blood Groups Biochem. Genet., 5, 95-104.

SENGUPta B.P., 1974. Distribution of red cell potassium and evidence of its genetic control in buffaloes. J. Agric. Sci., Camb., 82, 559-561. 